\title{
Peran Sanggar Seni Apo Lagaan terhadap Kontinuitas Sape' Karaang Dayak Bahau di Kota Samarinda Kalimantan Timur
}

\author{
The Role of the Apo Lagaan Art Studio on the Continuity of Sape' Karaang Dayak Bahau in \\ Samarinda City, East Kalimantan
}

Fernando Yonathan Tuah*, Program Studi Etnomusikologi, Fakultas Ilmu Budaya, Universitas Mulawarman. Email: yonathanfernando86@gmail.com

Asril Gunawan, Program Studi Etnomusikologi, Fakultas Ilmu Budaya, Universitas Mulawarman. Email: gunawanasril5@gmail.com

Zamrud Whidas Pratama, Program Studi Etnomusikologi, Fakultas Ilmu Budaya, Universitas Mulawarman. Email: zamrud.whidas@fib.unmul.ac.id

Received:
9 Agustus 2021
Accepted:
15 September 2021
Published:
30 Oktober 2021
Keywords:
the role of the art studio,
continuity of sape' karaang,
bahau dayak tribe
Kata kunci:
peran sanggar seni, kontinuitas
sape' karaang, suku dayak
bahau

Received:

9 Agustus 2021

15 September 2021

Published:

Keywords:

the role of the art studio, continuity of sape' karaang,

Kata kunci:

sape' karaang, suku dayak bahau

\begin{abstract}
:
The art studio Apo Lagaan first appeared in Samarinda in 2007 and is still going on today. The Apo Lagaan art studio is an art studio that focuses on the traditional arts of the Bahau Dayak, especially the music of sape' karaang. This study aims to reveal the form of the Apo Lagaan Art Studio's role, the form of presentation of sape' karaang, and the meaning contained in the game. This study uses a qualitative method. The observation technique used includes the object of research and the determination of informants. The data collection techniques of this research include literature study, interviews, and documentation. The research data analysis technique is carried out by utilizing the data that has been found in the field. The results showed that the Apo Lagaan Art Studio had a role in the continuity of the sape' karaang in Samarinda City. The role of the Apo Lagaan Art Studio on the continuity of the sape' karaang in Samarinda City is carried out through studio activities related to activities, training, and performances of traditional Dayak Bahau music and dance. In addition, the Apo Lagaan art studio has also expanded its partnerships to several government agencies and schools to provide education to the general public about the importance of cultural preservation, especially by the younger generation.
\end{abstract}

\footnotetext{
Abstrak:

Sanggar seni Apo Lagaan pertama kali muncul di Samarinda pada tahun 2007 dan masih bertahan hingga saat ini. Sanggar seni Apo Lagaan merupakan sanggar seni yang berfokus pada bidang kesenian tradisi Dayak Bahau khususnya musik sape' karaang. Penelitian ini bertujuan mengungkap bentuk peran Sanggar Seni Apo Lagaan dan bentuk penyajian sape' karaang serta makna yang terkandung dalam permainannya. Penelitian ini menggunakan metode kualitatif. Teknik observasi yang digunakan meliputi objek penelitian dan penentuan informan. Teknik pengumpulan data penelitian ini antara lain studi pustaka, wawancara, dan dokumentasi. Teknik analisis data penelitian dilakukan dengan memanfaatkan data-data yang telah ditemukan lapangan. Hasil penelitian menunjukkan bahwa sanggar seni Apo Lagaan memiliki peranan terhadap kontinuitas sape' karaang di Kota Samarinda. Peranan Sanggar Seni Apo Lagaan terhadap kontinuitas sape' karaang di Kota Samarinda dilakukan melalui aktivitas sanggar yang terkait dengan kegiatan, pelatihan, dan pementasan musik dan tari tradisi Dayak Bahau. Di samping itu, sanggar seni Apo Lagaan juga memperluas kemitraannya ke beberapa instansi pemerintah dan sekolah-sekolah guna untuk memberikan edukasi kepada masyarakat awam akan pentingnya pelestarian budaya terutama oleh generasi muda.
} 


\section{Citation:}

Tuah, F. Y., Gunawan, A., \& Pratama, Z. W. (2021). Peran Sanggar Seni Apo Lagaan terhadap Kontinuitas Sape' Karaang Dayak Bahau di Kota Samarinda Kalimantan Timur. Jurnal Mebang: Kajian Budaya Musik dan Pendidikan Musik, 2(1), 93106. https://doi.org/10.30872/mebang.v1i2.12

\section{Pendahuluan}

Dayak Bahau merupakan salah satu Sub Suku Dayak yang mendiami pedalaman Pulau Kalimantan, khususnya di daerah Kabupaten Kutai Barat dan Kabupaten Mahakam Ulu Provinsi Kalimantan Timur (Ahyat, 2016). Kehidupan masyarakat Dayak Bahau pada umumnya bermukim di sepanjang pinggir Sungai Mahakam, mulai dari Kecamatan Tering, Laham, Long Hubung, Long Bagun, Long Pahangai dan Long Apari. Masyarakat Dayak Bahau tidak dapat terpisahkan dengan kehidupan alamnya serta aturan norma-norma adat istiadatnya. Suku Dayak Bahau selain memiliki keberagaman adat istiadat juga dikenal kaya akan bentuk kesenian tradisinya secara turun temurun hingga saat ini (Hamdani, 2020).

Konsep keteraturan dalam produk kebudayaan serta adat istiadat tentu saja bagian dari proses kontinuitas terhadap norma maupun kesenian. Hal ini dimaksudkan bahwa prinsip keteraturan sejatinya bagian dari interaksi sosial yang berjalan secara dinamis sehingga menciptakan peluang terhadap stabilitas budaya termasuk ritus dan kesenian, khususnya kontinuitas musik Sape' Karaang. Oleh karena itu, kegiatan upacara, kesenian dan kepercayaan sudah menjadi aturan yang patut dilaksanakan karena syarat akan nilai adat dan makna simboliknya. Disisi lain, masyarakat Dayak Bahau meyakini adanya perlindungan dan berkat dari Tuhan Yang Maha Kuasa (Ame Tinge). Artinya, hubungan kesenian dan ritual dalam masyarakat Dayak Bahau, terkait erat dengan aspek-aspek kehidupan seperti, adat perkawinan (Dange Hawaa), adat pemberian nama anak (Dange Anaak), adat berladang (Hudo'), adat kematian (Ku' On, Peleka' Beruaan/To') (Lie et al., 2020). Bentuk upacara tersebut saling berkorelasi terhadap kesenian khususnya musik Sape' Karaang sebagai proses ritual adat dan hiburan. Hingga saat ini keberadaan Sape' Karaang masih disakralkan oleh masyarakat Dayak Bahau khususnya bagi Sanggar Seni Apo Lagaan di Samarinda Kalimantan Timur.

Sanggar adalah tempat untuk kegiatan berkesenian yang meliputi; seni musik, tari, lukis, dan jenis seni lainnya. Salah satu pelestarian budaya terhadap bentuk karya seni khususnya bidang musik yaitu dengan didirikannya sanggar seni. Sanggar seni merupakan sarana yang digunakan suatu organisasi yang bergerak dibidang seni. Pendidikan di sanggar seni yaitu mempelajari berbagai macam jenis kesenian yang sudah ada baik berupa musik dan tari klasik maupun kreasi. Dalam pengembangannya, selain melestarikan kesenian tradisi, sanggar seni juga mengembangkan bentuk-bentuk kesenian baru untuk melakukan suatu pertunjukan sebagai bukti keberadaan sanggar seni tersebut hidup di tengah masyarakat.

Sanggar Seni Apo Lagaan adalah komunitas seni yang bergerak pada wilayah praktik seni tradisi Dayak Bahau di Kota Samarinda. Secara historis, keberadaan Sanggar Seni Apo Lagaan di Samarinda, awalnya terbentuk pada tahun 2007 tepatnya tanggal 10 Oktober dan kemudian resmi berbadan hukum pada tahun 2011. Sebelum menggunakan nama Apo Lagaan, sanggar ini semula disebut sebagai "Ange Ngetan Midaang" yang beranggotakan beberapa orang saja dan hampir semua pesertanya adalah wanita. Penamaan grup sanggar tersebut pada dasarnya sangat sulit diucapkan oleh sebagian orang awam dikarenakan terlalu panjang dan menggunakan bahasa Dayak Bahau. 
Seiring berjalannya waktu, sanggar ini mulai diundang untuk tampil di beberapa event di kota Samarinda dan bahkan terlibat sebagai pelatih di beberapa tempat termasuk Dinas Pariwisata Provinsi Kalimantan Timur. Peserta sanggar "Ange Ngetan Midaang" saat itu juga mulai berkembang di mana keanggotaannya sudah terdiri dari penari laki-laki dan perempuan dalam setiap latihan gabungan bersama grup dari Dinas Pariwisata Provinsi Kalimantan Timur. Berdasarkan peristiwa tersebut kemudian sanggar "Ange Ngetan Midaang" saat tampil dalam suatu acara tertentu, yang secara tidak disengaja saat momen yang bersamaan terlintaslah nama yang disebut dengan "Apo Lagaan" dan penyebutannya bertahan hingga saat ini menjadi Sanggar seni "Apo Lagaan".

Keberadaan Sanggar Seni Apo Lagaan sebagai komunitas seni di Kalimantan Timur memiliki peran andil terhadap kontinuitas kesenian tradisi masyarakat Dayak Bahau. Hal tersebut juga penting sebagai bentuk edukasi bagi generasi penerus agar budaya tradisi khususnya budaya musik Dayak bahau yakni Sape' Karaang tidak hilang karena pengaruh perkembangan zaman. Peranan Sanggar Seni Apo Lagaan menunjukkan keterlibatan dan keikutsertaan individu atau organisasi yang melakukan suatu usaha untuk mencapai tujuan tertentu atas tugas serta bukti yang merupakan kewajiban dan harus dilakukan sesuai dengan kedudukannya. Peranan Sanggar Seni Apo Lagaan sebagai suatu organisasi pelestarian kebudayaan khususnya seni musik Sape' Karaang, melakukan aktivitas sanggar melalui kegiatan berkesenian antara lain; penggarapan, pelatihan, dan pementasan musik dan tari untuk mengembangkan potensi kesenian tradisi yang ada.

Penelitian Sape' Karaang diperlukan pemahaman tertentu dalam pendekatannya dengan konsep atau yang disebut pendekatan teori. Dalam penelitian ini penulis menggunakan teori Struktural Fungsional oleh Talcott Parson dan Teori Semiotika Teater oleh Tadeusz Kowzan. Teori struktural fungsional menjelaskan bahwa masyarakat adalah suatu sistem sosial yang terdiri dari bagian dan struktur-struktur yang saling berkaitan dan saling membutuhkan keseimbangan, struktural fungsional lebih mengacu pada keseimbangan (Rohmaniah, 2014). Bahasan teori tersebut menjelaskan sejumlah asumsi bagaimana persoalan terhadap musik Sape' Karaang saling terkait dan berkesinambungan dengan masyarakat pendukungnya. Kondisi lainnya juga dipengaruhi pada aspek geografis dikarenakan masyarakat Dayak Bahau terletak di pedalaman hulu Sungai Mahakam sehingga akses dalam penyebarannya menjadi sangat sulit. Oleh karena itu, teori Talcott Parson menjadi acuan dalam melihat komunitas masyarakat sebagai tindakan yang terintegrasi (keserasian) khususnya peran Sanggar Seni Apo Lagaan di Samarinda dalam mendukung kontinuitas musik Sape' Karaang.

\section{Metode}

Pendekatan kualitatif dengan metode deskriptif analisis digunakan dalam penelitian. Penelitian kualitatif, yaitu tahap sebelum ke lapangan (pralapangan) dengan studi kepustakaan, tahap kerja lapangan dengan observasi dan wawancara, analisis data dengan kerja laboratorium, dan penulisan laporan (Moleong, 2008:109). Tahap observasi dilakukan sebagai langkah awal melakukan penelitian, meliputi pengamatan, pencatatan, dan pendekatan secara langsung di lapangan. Observasi dilakukan dengan cara pengamatan secara langsung di lokasi yang digunakan untuk latihan rutin Sanggar Seni Apo Lagaan. Setelah itu, dilakukan penentuan informan dan wawancara langsung untuk mencari tahu kebenaran observasi terhadap permasalahan atas objek. Objek utama penelitian ini adalah kesenian Sape' Karaang Dayak Bahau di Kota Samarinda Kalimantan Timur. Selain observasi, teknik pengumpulan data juga dilakukan melalui studi kepustakaan, wawancara, dan dokumentasi. Langkah terakhir adalah 
teknik analisis data. Data yang telah diperoleh dari studi kepustakaan, observasi, wawancara, dan dokumentasi kemudian dianalisis untuk dijadikan tulisan. Hasil analisis data yang dianggap relevan dengan pembahasan masalah kemudian dituliskan secara deskriptif berbentuk narasi dan notasi.

\section{Hasil dan Pembahasan}

\subsection{Gambaran Umum Suku Dayak Bahau}

Dayak Bahau adalah salah satu sub etnik Dayak yang pada umumnya bermukim di sepanjang pinggir Sungai Mahakam, mulai dari Kecamatan Tering, Laham, Long Hubung, Long Bagun, Long Pahangai dan Long Apari. Masyarakat Suku Dayak Bahau memiliki mata pencaharian yang beragam di antaranya adalah berladang dengan sistem ladang berpindahpindah, artinya mereka memiliki lebih dari satu ladang (Handayani \& Setiawati, 2015). Kemudian mata pencaharian yang kedua adalah berburu dihutan dan mencari ikan di sungai. Lalu mata pencaharian Suku Dayak Bahau yang selanjutnya adalah meramu berbagai macam bahan-bahan yang berasal dari hutan, sebagai contohnya adalah daun-daunan, dammar, kayu, rotan, buah-buahan.

Masyarakat Dayak Bahau tidak dapat terpisahkan dengan kehidupan alamnya serta aturan norma-norma adat istiadatnya. Suku Dayak Bahau selain memiliki keberagaman adat istiadat juga dikenal kaya akan bentuk kesenian tradisinya secara turun temurun hingga saat ini (Hamdani, 2020:5). Suku Dayak Bahau memiliki budaya yang khas, yang tidak dimiliki oleh suku lainnya (Handayani \& Setiawati, 2015). Dayak Bahau dikenal dengan seni tato (Tedaak) yaitu seni melukis tubuh serta terkenal juga dengan ciri khas wanitanya yang bertelinga panjang (Huvat, 2014). Kini Dayak Bahau terbagi dalam tiga subkelompok, yakni Bahau Modang, Bahau Busang dan Bahau Saq.

Dalam kehidupan masyarakat suku Dayak Bahau, terdapat beberapa budaya ide atau konsep yang ada dalam suku Dayak Bahau di antaranya: sistem kekerabatan, hubungan sosial masyarakat (gotong royong) dan strata sosial (kasta).

\subsubsection{Sistem Kekerabatan (Kekeluargaan)}

Sama seperti bahasa, kekerabatan pun merupakan suatu sistem komunikasi. Bahasa adalah sistem komunikasi karena informasi atau pesan-pesan disampaikan oleh suatu individu kepada individu lain (Munir, 2016). Sistem Kekerabatan adalah unit-unit sosial yang terdiri dari beberapa keluarga yang memiliki hubungan darah atau hubungan perkawinan, sehingga dapat dikatakan sistem kekerabatan merupakan sebuah sistem yang dapat menggambarkan silsilah sebuah keluarga, sistem kekerabatan juga bisa disebut sebagai unit sosial yang memiliki hubungan darah seperti keluarga (Handayani \& Setiawati, 2015, p. 6). Pada sistem kekerabatan ini akan dijelaskan pula mengenai macam sistem kekerabatan dan kelompok kekerabatan. Dalam kehidupan masyarakat Suku Dayak Bahau, bentuk kekerabatan yang mereka terapkan dalam kehidupan kekeluargaannya adalah prinsip kekerabatan bilateral yaitu menghitung hubungan masyarakat melalui laki-laki dan sebagian perempuan. Pada masyarakat suku Dayak Bahau juga menerapkan sistem ambilinial dengan menggolongkan harta milik keluarga. Pada zaman dahulu kelompok kekerabatan yang diterapkan suku Dayak Bahau adalah kelompok ambilinial, namun kini sistem Utrolokal sudah diterapkan pada kehidupan sehari- 
hari (Handayani \& Setiawati, 2015). Menurut Kamus Besar Bahasa Indonesia, Utrolokal merupakan adat yang memberi kebebasan kepada pasangan pengantin baru untuk tinggal menetap di dekat keluarga suami atau istri.

\subsubsection{Hubungan Sosial Masyarakat (Gotong Royong)}

Suku Dayak Bahau masih menerapkan gotong royong dalam kehidupan sehari-hari guna mengakrabkan antar sesama masyarakat. Dalam kehidupan masyarakat Suku Dayak Bahau, gotong royong dilakukan hampir setiap acara, seperti pada saat akan melaksanakan upacara perkawinan para warga gotong royong untuk membantu pihak yang akan menikah dengan mempersiapkan tempat maupun barang-barang yang dibutuhkan.

\subsubsection{Strata Sosial (Kasta)}

Strata sosial juga bisa di sebut sebagai penggolongan atau tingkatan sosial orang-orang yang berada dalam lapisan-lapisan masyarakat. Pada stratifikasi sosial terdapat golongan keturunan dan lapisan masyarakat. Suku Dayak Bahau memiliki strata sosial, sama seperti suku-suku bangsa lainnya di seluruh Kepulauan Indonesia. Terdapat golongan Raja, Bangsawan, Kepala suku di satu pihak sedangkan di pihak lain terdapat golongan rakyat biasa atau orang awam. Golongan raja adalah golongan yang paling berkuasa dibandingkan golongan-golongan lain. Bangsawan adalah golongan keturunan yang terhormat, bangsawan masih mempunyai hubungan dengan raja, biasanya anak atau saudara. Kepala suku adalah orang yang paling punya wewenang, segala hukum adat dan upacara adat dipimpin oleh kepala suku. Golongan rakyat biasa/orang awam adalah tingkatan golongan terendah dalam strata sosial, atau dalam kata lain orang biasa adalah masyarakat.

Menurut Musyawarah Budaya pada tanggal 28-30 November 2018 di Amin Ayaa' Long Bagun Hudik (Rumah Besar/Lamin Besar Kampung Long Bagun Ulu), telah mempertegas dan menyepakati mengenai tingkatan sosial suku Dayak di wilayah Mahakam Ulu dalam hal ini adalah Dayak Bahau, meliputi Bahau Busang dan Bahau Sa', antara lain: Hipui; Pagawaa; Telajaan Jaan Paha'; Panyin; Dipan; Hukang (Dewan Adat Dayak Wilayah Mahakam Ulu, 2019, p. 61).

\subsection{Profil Sanggar Seni Apo Lagaan di Samarinda Kalimantan Timur}

Penjelasan sebelumnya telah disebutkan bahwa Sanggar seni "Apo Lagaan" disebut sebagai "Ange Ngetan Midaang". Dikarenakan kesulitan dalam pengucapannya, oleh karena itu, nama "Ange Ngetan Midaang" diganti menjadi "Apo Lagaan" hingga saat ini. Apo Lagaan sendiri terinspirasi dari nama suatu tempat yang terdapat dalam mitos kepercayaan leluhur yang dikenal sebagai asal-muasal kebudayaan Kayaan. Tempat tinggal para Roh Mulia, yang kerap diutus oleh Tame Tinge Tipang Tenangaan (Roh Yang Maha Kuasa) untuk menolong manusia di bumi.

Berdasarkan konteks sejarah yang melatarbelakangi Sanggar Seni Apo Lagaan pertama kali muncul pada Agustus 2007 di Kota Samarinda. Awal didirikannya Sanggar Seni Apo Lagaan pada tahun 2007 belum mempunyai izin resmi dari pemerintah, karena pada saat itu keinginan dari para pengurus hanya ingin memberikan pembelajaran untuk melestarikan budaya khususnya kesenian Dayak Bahau di Kota Samarinda. Namun masa tersebut kelompok 
ini masih bernama Sanggar Tari Apo Lagaan. Selang berapa bulan kemudian pada tanggal 15 Desember 2007 diubah menjadi Sanggar Seni Apo Lagaan dengan tujuan kesenian tidak terbatas pada musik dan tarian saja, melainkan pada budaya yang terkait dengan budaya Bahau. Hingga masa akhirnya kesenian ini setelah empat tahun kemudian berkembang dengan meningkatnya daya minat peserta didik di Sanggar Seni Apo Lagaan dan telah resmi berbadan hukum pada tahun 2011.

Sanggar Seni Apo Lagaan sebagai sebuah organisasi seni memiliki peran penting terhadap keberlangsungan kesenian tradisi Dayak Bahau, hal tersebut penting dikarenakan sebagai sebuah bentuk edukasi bagi generasi penerus agar terus menjaga budaya tradisi khususnya budaya musik Dayak Bahau yakni Sape' Karaang agar tidak hilang karena pengaruh perkembangan zaman.

Sejauh ini, Sanggar Seni Apo Lagaan masih mempertahankan kesenian tradisinya sebagaimana Sape' Karaang bagian dari warisan leluhur. Sanggar Seni Apo Lagaan masih menganggap bahwa apa yang telah ditinggalkan oleh para leluhur terdahulu patut untuk dijaga. Di samping itu, sape' karaang juga masih memiliki peran dan fungsi dimasyarakat dengan menyesuaikan kondisi lingkungannya. Hal itulah yang menjadi alasan mengapa Sape' Karaang di Sanggar Seni Apo Lagaan dijaga, selain warisan leluhur juga penting untuk disebarluaskan pada masyarakat awam. Alasannya adalah meskipun musik sape' karaang disakralkan namun ia dapat juga menjadi musik hiburan bagi masyarakat awam. Meski demikian Sanggar Apolagan tidak hanya mengangkat sape' karaang saja melainkan juga kesenian Hudo', Karaang Kayo, dan Ngenyah.

Budaya musik Sape' Karaang hingga saat ini masih dapat kita jumpai meskipun keberadaannya tidak begitu populer jika dibandingkan dengan Sape' Ngenyah (Sape' String). Musik Sape' Karaang dan Sape Ngenyah merupakan dua bentuk budaya musik yang masingmasing memiliki keunikan sesuai dengan konteks budaya maupun adat istiadatnya. Kehadiran dua bentuk sape' tersebut secara tidak langsung turut memberikan penguatan terhadap kontinuitas dari budaya musik sape' di Kalimantan Timur, khususnya Sanggar Seni Apo Lagaan. Di sisi lain meskipun berbeda namun keduanya juga telah memberikan pengetahuan penting terhadap identitas budaya musik di Kalimantan Timur.

Sape' Karaang dalam penyebutannya dapat disesuaikan dengan konteks geografisnya. Adapun penyebutannya, wilayah Kampung Long Tuyoq, mayoritas penduduknya adalah Suku Bahau Long Gelaat menyebutnya dengan istilah Sape' Pok, kemudian kelompok Bahau Busang menyebutnya dengan istilah Sape' Karaang, lalu pada sub Bahau Sa' mengenalnya dengan istilah Sape' Habai, dan suku Dayak Kayaan Mendalam di Kalimantan Barat menyebutnya dengan istilah Sape' Dayung/Ting Dua'. Fungsi musik Sape' Karaang dari waktu ke waktu mengalami perubahan menurut kebutuhan masyarakat setempat. Namun dalam perkembangannya kini perlahan-lahan mengalami perubahan dari ritual menjadi hiburan. Hal yang mendasar adalah meskipun ia dihadirkan dalam bentuk hiburan namun ia tidak lepas dengan sifatnya yang masih disakralkan terlebih dalam konteks upacara adat. Oleh karena itu kesenian tradisi musik Sape' Karaang masih sangat penting untuk dijaga kontinuitasnya pada masyarakat Dayak Bahau. 


\subsection{Sanggar Seni Apo Lagaan dalam Konsep AGIL}

\subsubsection{Adaptasi Sanggar Seni Apo Lagaan}

Adaptasi merupakan fungsi penting dalam segala bentuk organisasi khususnya Sanggar Seni. Organisasi harus bisa menyesuaikan diri dengan lingkungan dan seluruh aspek kehidupan. Proses adaptasi dapat dilakukan salah satunya adalah melalui proses pembelajaran, sebagaimana pembelajaran Sape' Karaang pada Sanggar Seni Apo Lagaan.

Proses adaptasi di Sanggar Seni Apo Lagaan tentu saja tidak lepas dari proses pembelajaran sebagai bagian dari transmisi dan kontinuitas seperti yang telah dijelaskan di atas. Proses pembelajaran dan seiring berjalannya waktu, kegiatan berkesenian dari Sanggar Seni Apo Lagaan tentu juga banyak mengalami kendala. Adapun kendala yang sering dihadapi adalah minimnya fasilitas yang memadai. Fasilitas yang minim seperti; tempat berkesenian (latihan), kostum, alat musik, dan sound system. Di samping itu, hal yang menjadi kendala juga adalah sulitnya membentuk kaderisasi anggota yang disebabkan kurangnya minat generasi muda di Kota Samarinda. Disisi lain proses latihan terlebih saat mempelajari kesenian khususnya Sape' Karaang, minimnya narasumber di Kota Samarinda karena kebanyakan berada di Kabupaten Mahakam Ulu. Meski demikian, proses pembelajaran Sape' Karaang bukan berarti tidak berjalan atau hilang begitu saja, melainkan tetap ada sebagaimana ia masih bertahan di Sanggar Seni Apo Lagaan dan masih tetap bisa kita lihat ketika dibawakan dalam sebuah pertunjukan ataupun prosesi ritual adat.

Sanggar Seni Apo Lagaan memiliki bentuk adaptasi yang ditunjukkan dalam keterbukaan untuk menerima budaya lain sehingga lebih mudah berinteraksi atau bergaul dan memiliki rasa toleransi yang tinggi. Sangar Seni Apo Lagaan juga beradaptasi untuk mengembangkan budaya dengan cara membentuk sebuah organisasi yang di dalamnya adanya struktur, aturan, material, peralatan, dan atribut dan lambang. Adaptasi juga dilakukan dengan membangun jaringan melalui lembaga adat atau sanggar lain untuk mempermudah dalam pengembangan budaya tradisi suku Dayak Bahau.

Kegiatan latihan rutin Sanggar Seni Apo Lagaan diadakan di Museum Samarinda setiap hari Senin malam pukul 19.00-21.00 WITA yang dilakukan satu kali dalam seminggu. Latihan tambahan di luar jadwal kegiatan sanggar dilakukan apabila akan mengadakan persiapan pementasan, pergelaran, dan perlombaan atau festival. Kegiatan pelatihan dibutuhkan pelatih, siswa atau anggota, materi, dan metode. Kegiatan awal pelatihan di Sanggar Seni Apo Lagaan dimulai dengan doa bersama. Doa bersama bertujuan agar proses latihan berjalan dengan lancar dan tidak terjadi hal yang tidak diinginkan. Setelah doa bersama selesai, dilanjutkan dengan pemanasan. Pemanasan dilakukan sekitar 5-10 menit sesuai dengan arahan pelatih.

Materi kegiatan pelatihan yang diajarkan di Sanggar Seni Apo Lagaan akan disesuaikan dengan tingkat penguasaan kelompok yang terdiri dari pemusik dan penari. Jenis musik dan tarian yang diberikan sanggar yaitu tari tradisi dan tari kreasi (penggarapan atau pengembangan gerak dan pola lantai). Hal tersebut salah satunya adalah tari tradisi Karaang Sape' dan musik Sape' Karaang. Karaang Sape' adalah tarian yang dalam penyajiannya menggunakan alat musik Sape' Karaang. Adapun dalam penyajian tarian Karaang Sape dan musik Sape' Karaang terbagi menjadi beberapa bentuk meliputi; Bunang Tataat, Tingang Nelise, Telaang usaan, Telaang Mayaak, Been, Dusang, Sung Segung, Tun Pate). Disamping 
itu, selain tarian Karaang Sape' di Sanggar Seni Apo Lagaan juga terdapat juga jenis tarian lain di antaranya adalah: Ngenyah, Karaang Kayo, Karaang Hudo', Kelepga'.

Konteks di atas sebenarnya tidak lepas dari peran musik itu sendiri, yang mana dalam hal ini Sape' Karaang dapat dilakukan atau dapat dimainkan tanpa adanya tarian, dengan kata lain Sape' Karaang murni sebagai instrumen yang dimainkan tanpa tarian atau berdiri sendiri. Penamaan judul musik pada Sape' Karaang tidak berbeda jauh dengan judul tariannya. Hal itu dikarenakan musik Sape' Karang dapat disesuaikan berdasarkan konteksnya baik sebagai instrumen pengiring tari, instrumen tunggal. Artinya, penamaan atau judul musik iringannya sama dengan judul tariannya. Sebagai contoh jika tari diawali dengan kata "karaang" yang artinya adalah tari atau menari, sedangkan pada musik menggunakan awalan kata "daak" yang artinya adalah tabuhan atau petikan. Misal Daak Bunang Tataat, Daak Tingang Nelise, Daak Telaang usaan, Daak Telaang Mayaak, Daak Been, Daak Dusang, Daak Sung Segung, Daak Tun Pate. Kata Daak, selain pada Sape' Karaang juga terdapat pada jenis musik lain seperti Daak Maraa', Daak Hudo'. Daak Maraa' dan Daak Hudo' dihadirkan dalam upacara ritual dan perlakuannya sangat berbeda dengan musik yang bersifat hiburan (Gunawan, 2020).

\subsubsection{Goal Attainment Sanggar Seni Apo Lagaan}

Proses pembelajaran yang dilakukan selama ini oleh Sanggar Seni Apo Lagaan secara tidak langsung mengarah pada proses goal attainment. Pengertian goal attainment secara umum adalah pencapaian tujuan, artinya adaptasi yang dilakukan Sanggar Seni Apo Lagaan melalui proses transformasi dan pembelajaran sejatinya memiliki sebuah tujuan seperti yang telah penulis jabarkan di atas, maka secara tidak langsung masyarakat mendapatkan suatu pengetahuan, sehingga dapat dipastikan pola tersebut menciptakan goal attainment itu sendri. Hasil dari proses pembelajaran di atas tidak lain sebenarnya adalah untuk mencapai proses goal attainment, hal ini dapat dilihat dalam proses pembelajaran dan latihan memiliki tujuan akhir yaitu dalam bentuk pementasan baik itu mengikuti event atau mengadakan pergelaran kesenian, semua itu dapat tercapai dan terlaksanakan setelah melalui proses latihan dan pembelajaran.

\subsubsection{Intergitas Sanggar Seni Apo Lagaan}

Integrasi pada Sanggar Seni Apo Lagaan tidak terlepas dari unsur masyarakat pendukungnya. Hal ini dapat dilihat dari keterlibatan Sanggar Seni Apo Lagaan dalam beberapa kegiatan ritual adat yang dilaksanakan di Kota Samarinda, di antaranya adalah prosesi Hudo' Kawit pada tahun 2012-2020, Dange Anaak \& Ayaa' di Loa Buah pada tahun 2016, Adat Hawa' hampir setiap tahun, dan Melaa' Tanaa' (pembersihan lahan). Keterlibatan Sanggar Seni Apo Lagaan pada rangkaian kegiatan tersebut terbagi di beberapa bagian penting yaitu sebagai pemusik (khusus laki-laki), beberapa anggota perempuan di kukuhkan menjadi Dayung ${ }^{1}$ muda yang nantinya bisa membantu para Dayung utama dalam menjalankan prosesi ritual adat.

\footnotetext{
1 Dayung adalah pemangku adat dalam bahasa Dayak Bahau
} 


\subsubsection{Latency Sanggar Seni Apo Lagaan}

Untuk tetap menjaga kelestarian tradisi-tradisi daerah maka perlu tindakan nyata dari Sanggar Seni Apo Lagaan secara khusus dengan metode Latency atau Pemeliharaan Pola. Mengingat bahwa sekarang ini banyak tradisi-tradisi yang mulai ditinggalkan atau terlupakan dikhawatirkan kebudayaan tradisi daerah tersebut mulai terabaikan. Proses Latency dapat dilakukan dengan pendekatan proses manajemen, artinya agar proses Latency di dalam organisasi atau sanggar dapat berjalan dengan baik maka dibutuhkan proses manajemen sehingga terjadilah pemeliharaan pola. Manajemen adalah suatu rentetan langkah yang terpadu untuk mengembangkan suatu organisasi atau sanggar seni sebagai suatu sistem yang bersifat sosio-ekonomis-teknis (Suganda, 2002, p. 221). Manajemen juga dapat diartikan sebagai semua kegiatan yang diselenggarakan oleh seseorang atau beberapa orang dalam suatu kelompok, organisasi atau lembaga dengan rancangan kegiatan yang dilakukan oleh perorangan, kelompok organisasi atau lembaga dalam hal ini ialah Sanggar Seni Apo Lagaan merupakan sebuah program (Katuuk et al., 2016).

Organisasi merupakan hubungan kerja antara orang-orang yang terdapat dalam usaha kegiatan. Sebuah organisasi juga menjamin kemampuan orang-orang yang ada di dalamnya agar dapat bermanfaat secara keseluruhan. Hal ini diwujudkan ke dalam bentuk struktur organisasi atau susunan pengurus yang dilengkapi dengan uraian pekerjaan yang berisi tugas dan wewenang setiap anggota serta kinerja antar bagian organisasi. Demikian juga halnya dengan Sanggar Seni Apo Lagaan mempunyai organisasi yang telah dibentuk dan terdiri dari beberapa orang yang bekerja sama untuk mencapai tujuan yang ingin dicapai.

Mengelola Sanggar Seni Apo Lagaan, pimpinan atau ketua sanggar dibantu oleh anggota lainnya seperti wakil ketua, sekretaris, bendahara 1 dan 2, divisi produksi, divisi pemasaran, divisi dokumentasi dan arsip, dan yang terakhir divisi perlengkapan yang telah di percaya untuk menjalankan tugas dan tanggung jawab sesuai dengan bidangnya masing-masing.

\subsection{Penyajian Sape' Karaang Dan Analisis Aspek Musikal}

Musik Sape' Karaang adalah salah satu jenis kesenian yang memiliki kekhasan dan keunikan. Adapun keunikan dari musik Sape' Karaang yaitu memiliki nuansa musikal yang sakral dan syarat akan maknanya. Berdasarkan sejarah lampau dikatakan, bahwa musik Sape' Karaang sering digunakan dalam upacara pengobatan dan menghidupkan orang yang sudah meninggal sambil diiringi tarian Telaang Mayaak dengan diiringi musik Sape' Karaang. Hingga saat ini, musik Sape' Karang masih dapat dijumpai dalam kegiatan ritual lainnya seperti adat kematian (Ku' On, Peleka' Beruaan/To'), dan upacara Hudo' Kawit pada Sanggar Seni Apo Lagaan di Samarinda Kalimantan Timur. Kesenian musik Sape' Karaang tersebar di sepanjang pinggiran Sungai Mahakam oleh Masyarakat Bahau, khususnya di wilayah Kabupaten Mahakam Ulu dan hingga Samarinda.

Bentuk adalah suatu wujud dari tata hubungan faktor-faktor yang mendukungnya dan saling berhubungan. Apabila kata bentuk digunakan dalam pengertian bentuk penyajian, maka bentuk penyajian musik adalah segala sesuatu yang disajikan atau ditampilkan ke penonton karena adanya unsur nilai-nilai keindahan yang disampaikan oleh pencipta kepada penikmat (Sari, 2013). Penjelasan di atas, menegaskan bahwa pertunjukan musik Sape' Karaang dalam konteks ritual tidak lepas juga dari penonton (penikmat). 
Berkaitan dengan konteks penyajian Sape' Karaang maka hal ini dapat dilihat dengan mengacu pada pendekatan Semiotika Tadeusz Kowzan. Semiotika Tadeusz Kowzan menyebutkan terdapat tiga belas tanda dalam sebuah pertunjukan. Berdasarkan pertunjukan musik Sape' karaang oleh Sanggar Seni Apo Lagaan, kemudian disesuaikan dengan pandangan Tadeusz Kowzan yang meliputi; instrumen musik, pemain, tata panggung, tata rias, tata busana, tata suara, tata lampu, formasi, dan urutan penyajian. Adapun penjelasan lebih lanjut sebagai berikut.

Instrumen. Instrumen yang digunakan dalam bentuk penyajian yang dibawakan oleh Sanggar Seni Apo Lagaan adalah Sape' Karaang itu sendiri, dan juga terkadang menambahkan instrumen lain seperti Agung (gong) dan Tuvung (tambur). Berdasarkan pengklsifikasinnya, instrumen Sape' Karaang merupakan alat musik Chordophone petik, sedangkan instrumen Agung adalah Idiophone dan Tuvung termasuk dalam kategori Membranophone. Berdasarkan fungsi instrumen dalam setiap pertunjukannya, musik Sape' Karaang berfungsi sebagai instrumen petik. Instrumen Agung dan Tuvung sebagai alat musik pukul yang dapat memberikan penguatan irama musikal dalam mengiringi Tarian Karaang Sape'. Hal itu menunjukkan bagaimana hubungan ketiga instrumen tersebut mampu menghasilkan jalinan irama musikal yang harmonis dan menghibur. Artinya, musik Sape' Karaang yang disertai dengan instrumen Agung dan Tuvung dalam hal ini disesuaikan dengan konteks pertunjukannya untuk hiburan. Sebaliknya ia akan menjadi musik sakral bilamana ia disajikan secara tunggal dalam prosesi upacara adat.

Pemain. Dalam hal ini diartikan sebagai pelaku yang terlibat secara langsung dalam setiap pertunjukan musik Sape' Karaang. Berdasarkan kondisi di Sanggar Apo Lagaan pelaku pada umumnya berasal dari mahakan ulu yang dominannya kini berdomisili di kota Samarinda. Adapun konsep pemain dapat dibagi ke dalam dua fungsi yang berbeda baik penari maupun pemusik. Penari dalam pertunjukan Sape' Karang disebut penari Karaang Sape', kemudian untuk pemain musik disebut sebagai Pemusik Sape' Karaang. Prinsip tersebut penting dalam melihat hubungan dan keterkaitan antara penari dan pemusik sebagai pelaku dari pertunjukan Sape' Karaang.

Panggung. Unsur terpenting lainnya dalam bentuk penyajian musik dan tari adalah panggung atau tempat penampilan. Sejauh ini tidak ada bentuk panggung khusus yang digunakan dalam pertunjukan musik Sape' Karaang baik dalam pertunjukan musik maupun sebagai iringan tari Karaang Sape' di Sanggar Seni Apo Lagaan. Hal ini dikarenakan panggung yang digunakan dapat disesuaikan dengan lokasi maupun tempat pertunjukannya. Di samping itu, penyajiannya dapat juga disesuiakan dengan berdasarkan pada fungsinya yaitu sebagai hiburan atau ritual. Pertunjukan yang bersifat hiburan umumnya lebih kondisional baik berupa panggung outdoor maupun Indoor. Namun, dalam pelaksanan ritual umumnya digunakan di lapangan terbuka khususnya disetiap prosesi upacara adat.

Tata Rias/Make Up. adapun tata rias pemain musik Sape' Karaang dalam pementasan di Sanggar Seni Apo Lagaan tidak menggunakan tata rias apa pun, tetapi hanya natural saja. Sedangkan untuk tata rias penari putri yang digunakan hanya berupa lipstik, pensil alis, dan bedak. Tata rias digunakan agak tebal pada malam hari dan agak tipis pada siang hari. Pada penari laki-laki hanya menggunakan sedikit bedak agar tidak terlihat pucat dan kusam. Di samping itu tata rias tidak terbatas pada bagian wajah saja melainkan juga pada bagian tubuh yang lain sebagaimana membuat motif tato pada bagian lengan dan kaki; (e) Tata Busana/Kostum, busana atau pakaian yang digunakan oleh pemusik dan penari Sanggar Seni Apo Lagaan pada penyajian musik Sape' Karaang dalam iringan Karang Sape' adalah pakaian 
adat khas suku Dayak Bahau. Tata busana yang digunakan oleh pemusik, yaitu bagian atasan menggunakan Basung (rompi) yang bermotif khas Suku Dayak Bahau, Lavung (Topi Dayak), sedangkan untuk bagian bawahan hanya menggunakan dan Bah (Cawat). Busana yang digunakan oleh penari putra adalah Bah (cawat), Basung (rompi), Sunung (bagian atas rompi) yang terbuat dari kulit sapi, kambing atau macan, bagian kepala yang dihiasi dengan Lavung Lagaa dan Lavung Kenlai. Sedangkan busana penari putri bagian atas memakai Telbe' khas Suku Dayak Bahau, baju bermanik dengan warna dasar hitam berlengan, Ta'ah (rok) khas Suku Dayak Bahau. Panjang rok yang digunakan hampir sepanjang mata kaki. Untuk kepala menggunakan Lavung Ube (topi khusus wanita). Terakhir aksesoris di tangan menggunakan gelang dan bulu enggang.

Tata Suara/Musik. Iringan dalam sebuah pementasan merupakan hal yang saling ketergantungan satu sama lain yang membuat semarak dan meriahnya suatu penampilan. Dalam bentuk penyajian musik Sape' Karaang di Sanggar Seni Apo Lagaan selalu menggunakan sound system atau pengeras suara, hal ini dilakukan mengingat karakter bunyi dari Sape' Karaang yang terkesan low sehingga membutuhkan sound system untuk mengeraskan suaranya. Suara yang dihasilkan pun menjadi lebih luas sehingga dapat didengar oleh banyak orang berkat pengeras suara.

Tata Lampu/Cahaya. Dalam pertunjukan kesenian tradisional musik Sape' Karaang sebagai iringan tari Karaang Sape' oleh Sanggar Seni Apo Lagaan menyesuaikan dengan situasi dan kondisi, jika pertunjukan diadakan pada malam hari maka pertunjukan menggunakan tata lampu penerangan atau cahaya, sebaliknya jika pementasan dilakukan pada siang hari maka tidak menggunakan penerangan.

Formasi Dan Gerak Tari. Suatu pertunjukan akan lebih menarik dan indah dilihat oleh penonton jika memiliki formasi atau pola lantai dalam setiap gerakan yang akan ditarikan. Pola lantai adalah garis-garis imajiner yang dilalui oleh penari atau garis-garis yang ditinggalkan oleh penari dalam membentuk sebuah pola atau formasi kelompok. Tidak ada formasi khusus untuk pemusik dalam pementasan, adapun formasi yang biasa digunakan adalah duduk berbaris memanjang ke samping, di mana posisi pemain musik menyesuaikan dengan jumlah pemain dan kondisi space yang ada biasanya berada disisi samping kanan atau kiri panggung. Sementara itu, posisi penari saat tampil berada di tengah panggung, kemudian akan berpindah-pindah formasi mengikuti pola lantai yang telah disepakati bersama antar penari. Tari Karaang Sape' memiliki beberapa ragam gerak, yang tersusun di dalam tahapantahapan yaitu gerak pembuka, gerak pola 1, gerak pola 2, gerak pola 3, gerak pola 4 dan gerak penutup. Susunan pola gerak sebenarnya tidak memiliki jumlah minimal atau maksimal, semua kembali pada kesepakatan bersama antar penari dalam proses latihan untuk menentukan berapa pola lantai yang akan digunakan.

Urutan Penyajian. Dalam pertunjukan kesenian musik dan tari di Sanggar Seni Apo Lagaan meliputi beberapa tahapan yaitu; tahap persiapan, tahap pelaksanaan, dan tahap akhir.

\subsubsection{Hubungan Sape' Karaang dengan Tarian}

Berbeda dengan Sape' Ngenyah, Sape' Karaang hanya memiliki 2 senar saja dengan skala nada pentatonik do, $\mathrm{mi}$, fa, sol, la dalam sistem tangga nada barat. Dari segi warna suara pun juga Sape' Karaang ketika dimainkan akan menghasilkan suara yang lebih Low (rendah). Sape' Karaang juga mempunyai keunikan dibalik tangga nadanya sangat minim dan musik yang monoton ketika dimainkan, alat musik ini mempunyai sekitar 20 (dua puluh) judul musik 
berserta dengan tariannya. Pada Sape' Karaang musik dan tarian adalah satu kesatuan yang tidak dapat dipisahkan, di mana satu judul pada musik Sape' Karaang akan menghasilkan 1 tarian, jadi sederhananya adalah satu musik hanya untuk satu tarian.

Dalam penyajian musik Sape' Karaang dalam iringan tarian Karaang Sape', ada beberapa macam bentuk atau format penyajian yang dibawakan oleh Sanggar Seni Apo Lagaan. Pertama, adalah dalam penyajiannya tidak menggunakan bantuan alat musik lain sebagai iringan, murni ia berdiri sendiri menjalankan tugasnya sebagai alat musik tunggal pengiring tari Karaang Sape'. Kedua, yaitu dalam penyajiannya menambahkan unsur musik instrumen tambahan seperti Agung dan Tuvung sebagai iringan tari Karaang Sape'. Ketiga, jumlah penari menyesuaikan situasi dan kondisi di lokasi pementasan, dengan kata lain tidak ada batasan tertentu untuk jumlah penari (boleh tunggal atau grup).

\subsubsection{Makna Totemisme dalam Musik Sape' Karaang}

Musik Sape' Karaang adalah permainan musik dengan instrumen Sape' berdawai 2 (dua). Permainan musik Sape' Karaang di Sanggar Seni Apo Lagaan dimainkan oleh 1 orang dan beberapa orang penari. Kesenian ini sangat sederhana baik dari bentuk musik maupun penampilan pemainnya, tetapi bunyi yang dihasilkan sangat terdengar mistis dan di dalamnya sarat akan makna. Musikal Sape' Karaang sebagai tindakan simbolis yang dapat menjadi sarana komunikasi budaya khususnya dalam setiap upacara adat. Makna yang terkandung dalam setiap penyajian musik Sape' Karaang sangat erat dengan kaitannya terhadap konsep "Totemisme". Totemisme adalah gejala yang berhubungan langsung dengan individu dan kelompok tertentu (Alfons, 2020). Individu atau kelompok tersebut memiliki hubungan yang khusus dengan objek alam baik itu tumbuhan, hewan ataupun benda lainnya. Objek tersebut dianggap memiliki hubungan khusus yang bersifat "mistik". Bagi masyarakat Dayak Bahau yang masih memiliki sistem kepercayaan totemisme yang menganggap bahwa hewan atau tumbuhan tertentu memiliki suatu bentuk kesakralan dan selalu terpelihara dari zaman dahulu hingga sekarang.

Totemisme dalam Sape' Karaang dapat kita temukan pada penggunaan nama hewan sebagai judul musik, di antaranya: bunang (katak), tingang (enggang), been \& dusang (jenis ikan air tawar). Sejauh ini memang belum ada informasi jelas mengapa dan bagaimana namanama hewan ini terkait erat dengan musik Sape' Karaang. Namun, berdasarkan pengamatan penulis, penggunaan nama hewan pada judul musik Sape' Karaang berhubungan dengan gerak tarian. Hal itu tidak lepas dari makna gerakan yang terinspirasi dari hewan itu sendiri. Sebagai contoh, pada musik Bunang Tataat, gerak tarinya pun mengambil beberapa gerakan yang menggambarkan seekor katak yang sedang melompat. Hal yang sama juga terdapat pada beberapa judul musik lainnya seperti: Tingang Nelise, Been dan Dusang yang juga terinspirasi dari masing-masing hewan tersebut yaitu; burung Enggang dan ikan Been dan Ikan Dusang.

Hal tersebut di atas menunjukkan bahwa musik dan tari pada Sape' Karaang secara makna saling terhubung dan saling berkolerasi satu dengan yang lain. Terpelihara sistem kepercayaan ini berkaitan dengan pemaknaan terhadap hewan leluhur yang dianggap sakral.

\subsubsection{Analisis Musik Sape' Karaang}

Sanggar Seni Apo Lagaan tidak pernah menggunakan penotasian dalam setiap proses pembelajarannya, melainkan dilakukan secara lisan. Meski demikian semangat pembelajaran 
musik yang telah diterapkan secara lisan pun masih tetap bertahan hingga saat ini. Berkenaan dengan analisis musik, maka penulis menggunakan pendekatan musik barat. Hal ini bukan berarti analisis musik Barat dapat mewakili keseluruhan representasi dari aspek musikal Sape' Karaang. Melainkan digunakan sebagai pertimbangan dalam konteks analisis musik secara umum. Misal penggunaan teori Weighted Scale yang di antaranya terdiri tangga nada, nada dasar, wilayah nada, jumlah nada, interval, pola kadens, formula melodis dan kontur.

Berdasarkan temuan di lapangan dan hasil transkripsi notasi di atas, bentuk musikal dan pola permainan Sape' Karaang kecenderungannya sangat monoton atau biasa disebut dengan istilah "Repetisi" yaitu permainan musik yang dilakukan secara berulang-ulang. Pada musik Bunang Tataat dan Tingang Nelise tangga nada dan nada dasar yang digunakan sama yaitu tangga nada $\mathrm{C}$ minor. Yang membedakan antara Bunang Tataat dan Tingang Nelise terdapat pada pola permainan. Permainan musik Bunang Tataat terdiri dari dua bagian, dan pada bagian kedua musik Bunang Tataat tedapat pengulangan. Sedangkan pada musik Tingang Nelise hanya terdiri dari satu bagian yang di mainkan secara berulang-ulang. Sementara itu, pada musik Tun Pate terdapat nada disonan, yang merupakan nada di luar tangga nada C minor, nada tersebut adalah $\mathrm{C \# .}$

\section{Simpulan}

Peran Sanggar Seni Apo Lagaan terhadap kontinuitas musik Sape' Karaang Dayak Bahau di Kota Samarinda dapat dilihat melalui proses transformasi, kegiatan pelatihan, hingga pementasan. Berdasarkan kegiatan yang dilakukan Sanggar Seni Apo Lagaan, maka dapat dilihat peranan Sanggar Seni Apo Lagaan terhadap kontinuitas musik Sape' Karaang. Peran Sanggar Seni Apo Lagaan juga dapat dilihat dalam mengembangkan seni dan budaya Dayak Bahau dengan kreativitas secara terus-menerus agar lebih baik. Melalui kegiatan pelatihan kesenian tradisi Dayak Bahau dan bentuk pementasan yang merupakan usaha penyebaran yang dilakukan oleh Sanggar Seni Apo Lagaan agar lebih luas dan dikenal oleh masyarakat di Samarinda. Faktor pendukung yang memengaruhi peran Sanggar Seni Apo Lagaan, yaitu jalinan kerja sama dengan lembaga pemerintah, sekolah formal, dan masyarakat di Kota Samarinda. Kreativitas Sanggar Sanggar Seni Apo Lagaan dalam mengembangkan Kesenian Dayak Bahau khususnya Sape' Karaang. Sebagai pelopor/penggerak masyarakat untuk mengembangkan dan melestarikan Kesenian Dayak Bahau di Samarinda. Memiliki anak didik sebagai generasi penerus dalam mengembangkan seni dan budaya suku Dayak Bahau, serta mencapai prestasi dibidang kesenian dan kebudayaan.

\section{Referensi}

Alfons, C. R. (2020). Totemisme di Era Modernisasi: Realitas Masyarakat Adat Negeri Hutumuri Kecamatan Leitimur Selatan Kota Ambon. 3(2), 89-100.

Dewan Adat Dayak Wilayah Mahakam Ulu. (2019). Kitab Hukum Suku Dayak Mahakam Ulu. Kota Tua Malang.

Fajriansyah, A. A., Vivian, Y. I., \& Pratama, Z. W. (2021). Fungsi Daak Maraa' dalam Upacara Hudo' Kawit pada Masyarakat Suku Dayak Bahau di Kota Samarinda. Jurnal Mebang: Kajian Budaya Musik dan Pendidikan Musik, 1(1), 14-24. https://doi.org/10.30872/mebang.v1i1.2 
Gunawan, A. (2020). Makna Simbolik Musik Daak Maraaq dan Daak Hudoq dalam Upacara Hudoq Bahau di Samarinda Kalimantan Timur. Resital, 21(2), 113-126. https://doi.org/https://doi.org/10.24821/resital.v21i2.4462

Hamdani, M. (2020). Khazanah Seni Tradisi Kalimantan Timur. Samarinda: Dewan Kesenian Daerah Kalimantan Timur.

Handayani, N. M., \& Setiawati, F. (2015). Suku Dayak Bahau. 1-25.

Huvat, Y. J. (2014). Teknik Permainan Mmusik Sapeq Dalam Budaya Masyarakat Suku Dayak Bahau. Jurnal Musik, 16.

Katuuk, O. M., Mewengkang, N., \& Kalesaran, E. R. (2016). Peran Komunikasi Organisasi Dalam Meningkatkan Eksistensi Sanggar Seni Vox Angelica. V(5), 1-10.

Lie, F. O., Purwanti, S., \& Boer, K. M. (2020). Makna Simbol Ritual Kematian Pada Suku Dayak Bahau Busang Di Kabupaten Mahakam Ulu. EJurnal Ilmu Komunikasi, 8(4), 26-36.

Moleong, L. J. (2008). Metode Penelitian Kualitatif. Bandung: PT. Reamaja Rosdakarya.

Munir, M. (2016). Sistem Kekerabatan dalam Kebudayaan Minangkabau: Perspektif Aliran Filsafat Strukturalisme Jean Claude Levi-Strauss. Jurnal Filsafat, 25(1), 1. https://doi.org/10.22146/jf.12612

Pratama, Z. W., Setyoko, A., \& Arozaq, F. Y. (2021). Ornamentasi Vokal pada Tarsul Kutai Kartanegara. Jurnal Mebang: Kajian Budaya Musik dan Pendidikan Musik, 1(1), 25-34. https://doi.org/10.30872/mebang.v1i1.3

Rohmaniah, S. (2014). Art Barong Role in Improving Participation in Pelem Village District Blora. SOSIALITAS: Jurnal Ilmiah Pend. Sos Ant, 4(1).

Sari, Y. L. (2013). Fungsi Dan Bentuk Penyajian Musik Thillung di Dagaran Jurug Sewon Bantul. Skripsi Universitas Negeri Yogyakarta, 1-7. https://eprints.uny.ac.id/19634/1/Yenni Lukita Sari 08208241020.pdf

Suganda, D. (2002). Manajemen Seni Pertunjukan. Bandung: PUSLITMAS STSI.

Yulinanda, D. B., Vivian, Y. I., \& Setyoko, A. (2021). Gagrak Blitaran: Proses Belajar Kebudayaan di Paguyuban Turonggo Budoyo Mugirejo. Jurnal Mebang: Kajian Budaya Musik dan Pendidikan Musik, 1(1), 1-13. https://doi.org/10.30872/mebang.v1i1.1 